\title{
Original Research \\ Changeability of Oxygen and Biogenic Indices in Waters Flowing through Areas under Various Anthropopressures
}

\author{
Włodzimierz Kanownik*, Agnieszka Policht-Latawiec \\ Department of Land Reclamation and Environmental Development, \\ University of Agriculture in Cracow, Al. Mickiewicza 24-28, 30-059 Cracow, Poland \\ Received: 12 May 2014 \\ Accepted: 3 January 2015
}

\begin{abstract}
Seasonal and monthly changes of biogenic and oxygen indices in the water of two streams in 2007-10 are discussed in this paper. The streams have similar catchment areas that area managed and used in different ways. The Krzyworzeka stream catchment is covered by rural areas, whereas the Serafa stream flows through built-up and urbanized areas.

Statistical testing using U Mann-Whitney's nonparametric test was conducted to determine the differences of oxygen and biogenic water quality index values between the growing season and outside the growing season. Statistically significant decreases in ammonium, nitrate, and total nitrogen concentrations, as well as oxygen dissolved in Krzyworzeka Stream, were registered during the growing season. In the Serafa water only the concentrations of dissolved oxygen and biological oxygen demand decreased significantly. On this basis it was established that in clean waters vegetation development considerably influences the content of biogenic compounds. Serious pollution of stream water causes vegetation and the intensity of biochemical processes in water to not cause any clear reduction in biogenic compound concentrations.
\end{abstract}

Keywords: water quality, water pollution, nutrients, stream, land use

\section{Introduction}

Spatial and time changeability of surface water quality results from anthropogenic activities in the catchment area $[1,2]$, growing pollutant amount [3], and environmental management [4]. The EU Water Framework Directive (WFD) [5] stipulates that the waters of all European strongly changed water bodies must achieve good ecological potential and good chemical status by 2015 [6, 7]. A considerable part of waters bodies in Europe is exposed to the risk of not achieving a good state by this year [8]. Therefore, water quality assessment and determining the factors affecting its changes have been the subject of

*e-mail: rmkanown@cyf-kr.edu.pl numerous papers [9-16]. The assessment process faces two main problems: complexity and uncertainty [17] - both due to high social and economic costs $[6,18]$. Changeability of water chemical parameters should be assessed on the basis of monitoring programs in order to detect changes in their quality status $[6,19,20]$. This aims to determine the main actions targeting restoration of good status of waters, which ensures that their quality would respond to the aims suggested by WFD for the human population, considering the principle of sustainable development and public health [21, 22]. Problems with water quality are associated with a great number of nutrients originating from surface runoff from urban areas [23] (including sewage discharge) $[2,24]$ and from agricultural areas $[7,25]$. 
Out paper presents seasonal and monthly changes of oxygen and biogenic index values in Krzyworzeka and Serafa streams over the 2007-10 multiannual period. The selection was motivated by various anthropogenic factors occurring in the catchment area. The Krzyworzeka stream catchment is used mainly for agricultural purposes, whereas the Serafa stream flows through built-up urban areas.

\section{Materials and Methods}

Our paper presents results of four-year hydrochemical analyses of oxygen indices: dissolved oxygen (DO) and biochemical oxygen demand $\left(\mathrm{BOD}_{5}\right)$; and biogenic indices: ammonium $\left(\mathrm{NH}_{4}-\mathrm{N}\right)$, total Kjedahl nitrogen (TKN), nitrite
$\left(\mathrm{NO}_{2}-\mathrm{N}\right)$, nitrate $\left(\mathrm{NO}_{3}-\mathrm{N}\right)$, total nitrogen $(\mathrm{TN})$, phosphate $\left(\mathrm{PO}_{4}\right)$, and total phosphorus (TP) in Krzyworzeka and Serafa streams, which have a major influence on the degradation and eutrophication of the water environment. Values of indices were obtained from the Regional Direction of the Natural Environment Inspectorate (WIOŚ) in Cracow. Water samples were collected in 2007-10, usually once a month in the villages of Czaslaw-Myto on Krzyworzeka Stream and Duza Grobla on Serafa Stream (Fig. 1).

The basic analysis characterizing oxygen and biogenic indices was based on statistical parameters describing the analyzed community (minimum, maximum, arithmetic mean, median, standard deviation, and coefficient of variance). Diversification of the studied indices among the measurement-control points was determined on the basis of

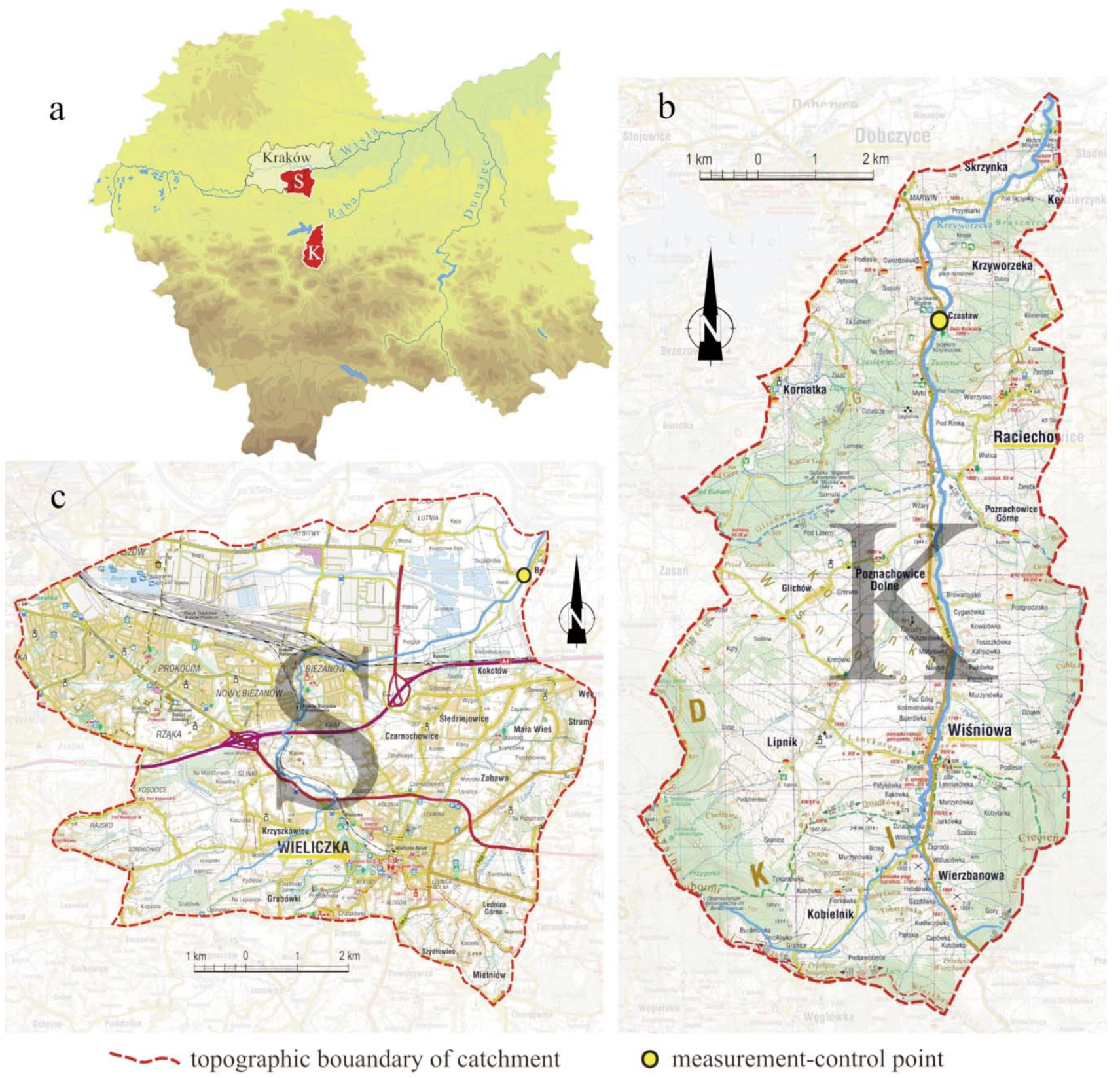

Fig. 1. Location of the Krzyworzeka (K) and Serafa (S) stream catchments against the background of the hydrographic network of Malopolskie Voivodship (a), the Krzyworzeka Stream catchment (b), the Serafa Stream catchment (c) (based on the materials of "Compass" Cartographic Publishers). 
cluster analysis by constructing the levels of hierarchical tree diagram using Ward's method. In the analyzed samples, the total-nitrogen-to-total-phosphorus ratio was determined as well as the share of individual nitrogen forms in relation to total nitrogen, phosphates, and total phosphorus.

Water quality classes were determined on the basis of mean value of oxygen and biogenic indices for the 2007-10 multiannual period, assuming the limit values in compliance with the decree of the Ministry of the Natural Environment [26]. Moreover, we determined mean values of oxygen and biogenic index concentrations during and outside the growing season. The period outside the growing season is the part of the year (from November to March) when average daily air temperature remains below $5^{\circ} \mathrm{C}$. The other part of the year (from April to October) is the growing season with the air temperature over $5^{\circ} \mathrm{C}$, characterized by intensive vegetation development. The nonparametric $\mathrm{U}$ Mann-Whitney's test was used to compare the values of oxygen and biogenic indices of water quality between these periods in order to determine the influence of vegetation on their change in the water of analyzed streams. We also analyzed monthly changes of oxygen and biogenic index values in the waters of the Krzyworzeka and Serafa streams.

\section{Description of the Studied Stream Catchments}

The catchment of Krzyworzeka stream is situated wholly in the area of Myslenice County in the central part of Malopolskie Voivodeship, about $30 \mathrm{~km}$ south of Cracow (Fig. 1a). Its area is $80.2 \mathrm{~km}^{2}$. The southern part of the catchment belongs to the Beskid Wyspowy Mountains mezoregion, the northern is part of the Wisnickie Foothills. The stream is about $18 \mathrm{~km}$ long. The head of the Krzyworzeka stream is situated under Lubomira peak at $800 \mathrm{~m}$ a.s.l. The stream is flowing north through Wisniowa, Poznachowice Done, and Czaslaw villages, and just before Dobczyce turns to the east toward Stadniki village, where at $230 \mathrm{~m}$ a.s.l it flows into the Raba River, about 6,200 m below Dobczyce Dam (Fig. 1b). The biggest tributaries of the Krzyworzeka are: Sikornica (right-bank) and Lipniki and Olszanica (left-bank).

The main land use forms are arable lands, forests, and afforested grounds, which cover $90 \%$ of the catchment area. The communes situated in the catchment use a poor sewage system. Wisniowa commune is inhabited by 7,102 people, of which about 1,600 are using a sewage system of a total length of $15.3 \mathrm{~km}$. Raciechowice commune, including Czaslaw village, inhabited by 4,093 people, possesses only $3.5 \mathrm{~km}$ of sewage serving 61 households in the center of Raciechowice. A majority of the catchment inhabitants are using septic tanks for household sewage, emptied periodically.

The Serafa stream catchment covers $74.9 \mathrm{~km}^{2}$. The stream is $12.7 \mathrm{~km}$ long. Its head is situated above Wieliczka town at $278 \mathrm{~m}$ a.s.l. (Fig. 1c). Its left-bank tributary, Malinowka, flows into the Serafa at $7+900 \mathrm{~km}$, and its other tributaries - Drwina Dluga and then Zabawka - from the right. The Serafa flows into the Vistula River in Brzegi village at $192 \mathrm{~m}$ a.s.1., $400 \mathrm{~m}$ below Przewoz barrage. Following Kondracki's physico-geographical division of Poland, the Serafa stream catchment covers the area included in three mezoregions: the southern area belongs to the Wieliczka Foothills, the central part to the Bochnia Foothills, and the northern borders to the Vistula Lowland. The catchment area is strongly changed due to human activity. A major part of the catchment is managed as a built-up and urbanized area. Residential areas of Wieliczka town are situated in the upper part (about 21,000 inhabitants), housing and industrial areas of the $12^{\text {th }}$ quarter of Cracow (Biezanow-Prokocim) are situated in the central part (63,000 inhabitants). The lower part of the catchment is a more sparsely built-up area with numerous water reservoirs that remained after sand and gravel excavation in the area of the Vistula terrace.

A potential source of pollution of Serafa stream water is sewage inflow from the Sewage Treatment Plant in Cracow-Plaszow. The plant was put into operation in 1974. It was extended and modernized within the framework of the "Sewage Treatment Plant Plaszow II in Cracow" project. The modernization included an increase in the throughput of the existing mechanical sewage treatment plant in Plaszow to $160,000 \mathrm{~m}^{3} /$ day. At present it is a biological-mechanical treatment plant with full thermal disposal of sewage sludge, meeting the current standards regarding sewage treatment. An additional source of pollutants for Serafa Stream are runoff of atmospheric precipitations from the residential and industrial areas, from roads and car parks.

\section{Results}

Catchments of both streams have similar areas and are situated at a small distance from each other, but differ strongly with their management and land use. The Serafa catchment is formed of suburban and urban areas, whereas the Krzyworzeka catchment covers rural areas with high proportion of ploughlands. The land management and use generate various sources of surface water pollution. In the rural areas these are runoffs from ploughlands and point sewage discharge from the residential areas, whereas in the urban area these are surface runoffs from house roofs, roads, car parks, and other paved areas, as well as sewage discharge from treatment plants. All these factors affect pollutant content and quality of surface water flowing through these areas.

A comparison of the water from the studied streams revealed big differences of the values of oxygen and biogenic indices between the Serafa and Krzyworzeka, as well as different shares of pollutants in water. Cluster analysis revealed diversification of the values of oxygen and biogenic indices in the analyzed streams. In both streams indices with similar values constitute three groups of different composition (Fig. 2). In the Krzyworzeka, the largest group is composed of $\mathrm{BZT}_{5}, \mathrm{Kjeldahl}$ nitrogen, $\mathrm{NO}_{2}-\mathrm{N}$, $\mathrm{NH}_{4}-\mathrm{N}$, total phosphorus, and phosphates, whereas the second consists of total nitrogen and $\mathrm{NO}_{3}-\mathrm{N}$, and dissolved 
Table 1. Descriptive statistics of oxygen and biogenic water quality indices in the Krzyworzeka (K) and Serafa (S) streams in $2007-$ 10 and determined quality classes.

\begin{tabular}{|c|c|c|c|c|c|c|c|}
\hline \multirow[b]{2}{*}{ Indices } & \multirow[b]{2}{*}{ Stream } & \multicolumn{4}{|c|}{ Index values $\left[\mathrm{mg} \cdot \mathrm{dm}^{-3}\right]$} & \multirow{2}{*}{$\begin{array}{l}\text { Standard } \\
\text { deviation }\end{array}$} & \multirow{2}{*}{$\begin{array}{l}\text { Coefficient of } \\
\text { variation }[\%]\end{array}$} \\
\hline & & Min & $\operatorname{Max}$ & $\begin{array}{c}\text { Average } \\
\text { (water class) }\end{array}$ & Median & & \\
\hline \multirow{2}{*}{$\begin{array}{l}\text { Dissolved oxygen } \\
\text { DO }\end{array}$} & K & 6.7 & 14.3 & 10.98 (I) & 11.0 & 1.80 & 16 \\
\hline & $\mathrm{S}$ & 0.4 & 8.7 & 5.76 (II) & 5.95 & 1.91 & 33 \\
\hline \multirow{2}{*}{$\begin{array}{l}\text { Biochemical oxygen } \\
\text { demand } \mathrm{BOD}_{5}\end{array}$} & $\mathrm{~K}$ & 0.3 & 5.5 & 1.24 (I) & 1.1 & 0.80 & 65 \\
\hline & S & 1.5 & 94.6 & 11.69 (BGS) & 6.20 & 18.82 & 161 \\
\hline \multirow{2}{*}{$\begin{array}{l}\text { Ammonium } \\
\mathrm{NH}_{4}-\mathrm{N}\end{array}$} & $\mathrm{K}$ & 0.02 & 0.67 & 0.14 (I) & 0.10 & 0.16 & 110 \\
\hline & S & 0.42 & 26.26 & 3.55 (BGS) & 1.87 & 4.68 & 132 \\
\hline \multirow{2}{*}{$\begin{array}{l}\text { Total Kjeldahl } \\
\text { nitrogen TKN }\end{array}$} & $\mathrm{K}$ & 0.25 & 3.5 & 0.63 (I) & 0.50 & 0.57 & 91 \\
\hline & $\mathrm{S}$ & 1.68 & 29.22 & 5.67 (BGS) & 4.01 & 5.63 & 99 \\
\hline \multirow{2}{*}{$\begin{array}{l}\text { Nitrite } \\
\mathrm{NO}_{2}-\mathrm{N}\end{array}$} & $\mathrm{K}$ & 0 & 0.06 & $0.02(-)$ & 0.02 & 0.01 & 63 \\
\hline & S & 0.01 & 0.7 & $0.22(-)$ & 0.17 & 0.15 & 71 \\
\hline \multirow{2}{*}{$\begin{array}{l}\text { Nitrate } \\
\mathrm{NO}_{3}-\mathrm{N}\end{array}$} & $\mathrm{K}$ & 0.1 & 3.6 & $1.51(\mathrm{I})$ & 1.40 & 0.84 & 55 \\
\hline & S & 0.2 & 12.36 & 4.97 (II) & 4.89 & 2.65 & 53 \\
\hline \multirow{2}{*}{$\begin{array}{l}\text { Total nitrogen } \\
\text { TN }\end{array}$} & K & 0.71 & 4.3 & 2.20 (I) & 2.00 & 0.99 & 45 \\
\hline & S & 6.11 & 29.43 & 10.91 (BGS) & 9.44 & 4.95 & 45 \\
\hline \multirow{2}{*}{$\begin{array}{l}\text { Phosphate } \\
\mathrm{PO}_{4}\end{array}$} & $\mathrm{~K}$ & 0.06 & 0.95 & 0.29 (II) & 0.25 & 0.19 & 66 \\
\hline & $\mathrm{S}$ & 0.03 & 9.32 & 1.36 (BGS) & 0.46 & 2.15 & 158 \\
\hline \multirow{2}{*}{$\begin{array}{l}\text { Total phosphorus } \\
\text { TP }\end{array}$} & K & 0.03 & 0.85 & 0.16 (I) & 0.13 & 0.14 & 89 \\
\hline & $S$ & 0.12 & 5.48 & 1.09 (BGS) & 0.67 & 1.19 & 108 \\
\hline
\end{tabular}

I - quality class I, ecological status "very good"; II - quality class II, ecological status "good"; BGS - below good status
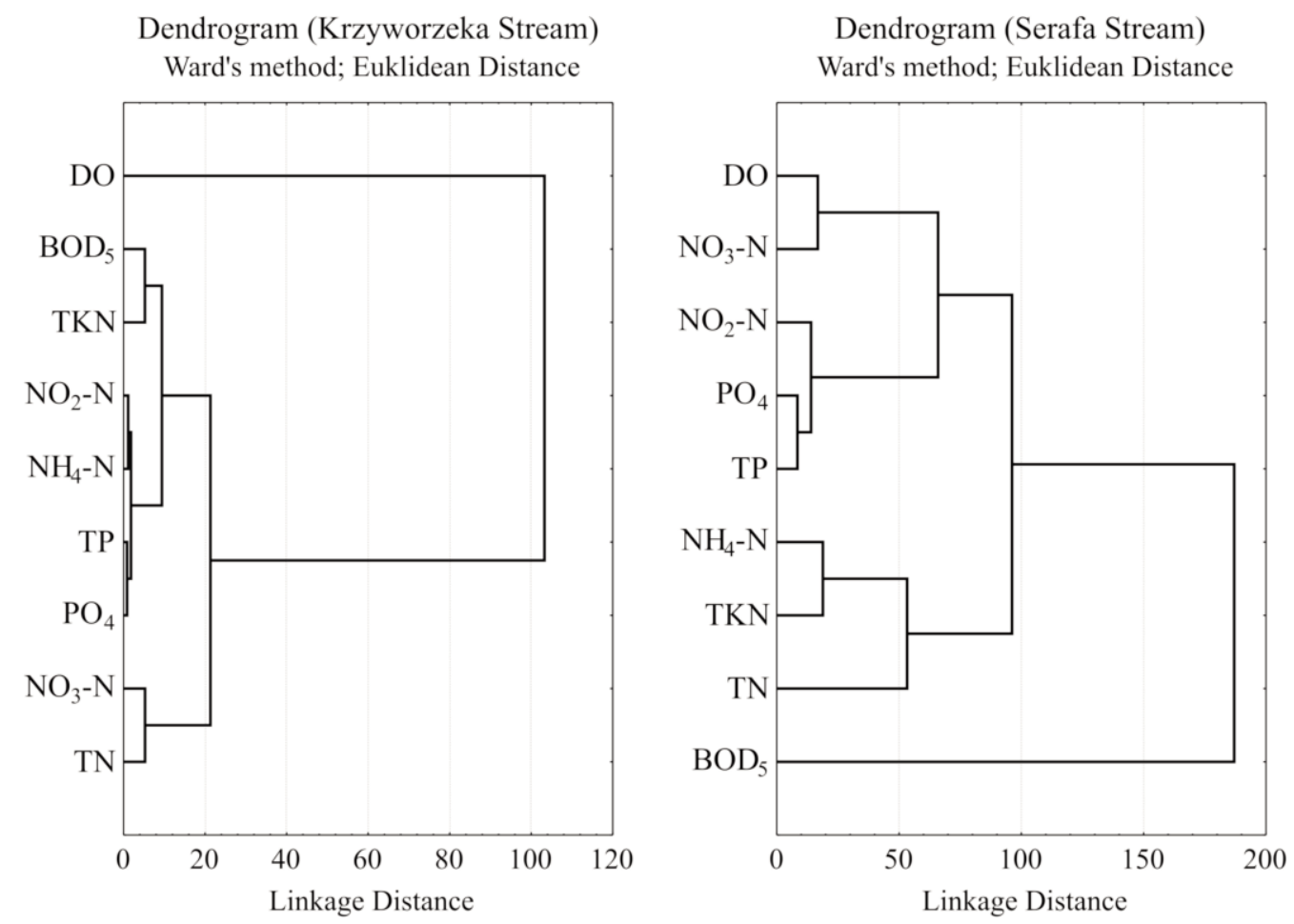

Fig. 2. Dendrogram (Ward's method) of the analyzed streams regarding selected physicochemical characteristics of water. 
Table 2. Comparison of values of oxygen and biogenic water quality indices between the growing season (GS) and outside the growing season (OGS) in the Krzyworzeka (K) and Serafa (S) streams; results of U Mann-Whitney's test.

\begin{tabular}{|c|c|c|c|c|c|c|c|c|}
\hline \multirow{2}{*}{ Indices } & \multirow{2}{*}{ Stream } & \multicolumn{2}{|c|}{ Median $\left[\mathrm{mg} \cdot \mathrm{dm}^{-3}\right]$} & \multicolumn{2}{|c|}{ Rank sums } & \multicolumn{2}{|c|}{ The values of statistic } & \multirow{2}{*}{$\begin{array}{l}\text { Probability } \\
\text { test }\end{array}$} \\
\hline & & OGS & GS & OGS & GS & $\mathrm{U}$ & Z & \\
\hline \multirow{2}{*}{$\begin{array}{l}\text { Dissolved oxygen } \\
\text { DO }\end{array}$} & $\mathrm{K}$ & 12.5 & 9.9 & 584.5 & 405.5 & 27.5 & 4.87 & 0.000 \\
\hline & $\mathrm{S}$ & 7.0 & 5.4 & 509 & 394 & 94 & 3.10 & 0.002 \\
\hline \multirow{2}{*}{$\begin{array}{l}\text { Biochemical oxygen } \\
\text { demand } \mathrm{BOD}_{5}\end{array}$} & $\mathrm{~K}$ & 1.1 & 1.1 & 419.5 & 570.5 & 192.5 & 0.90 & 0.371 \\
\hline & $\mathrm{S}$ & 7.55 & 4.75 & 515.5 & 387.5 & 87.5 & 3.27 & 0.001 \\
\hline \multirow{2}{*}{ Ammonium $\mathrm{NH}_{4}-\mathrm{N}$} & $\mathrm{K}$ & 0.13 & 0.09 & 468.5 & 521.5 & 143.5 & 2.09 & 0.036 \\
\hline & $\mathrm{S}$ & 2.43 & 1.38 & 471.5 & 431.5 & 131.5 & 2.15 & 0.032 \\
\hline \multirow{2}{*}{$\begin{array}{l}\text { Total Kjeldahl } \\
\text { nitrogen TKN }\end{array}$} & K & 0.50 & 0.50 & 338 & 565 & 185 & -0.73 & 0.467 \\
\hline & $\mathrm{S}$ & 4.43 & 3.08 & 454.5 & 448.5 & 148.5 & 1.72 & 0.086 \\
\hline \multirow{2}{*}{ Nitrite $\mathrm{NO}_{2}-\mathrm{N}$} & $\mathrm{K}$ & 0.02 & 0.01 & 292 & 449 & 172 & -0.02 & 0.987 \\
\hline & $\mathrm{S}$ & 0.16 & 0.18 & 376.5 & 526.5 & 205.5 & -0.27 & 0.789 \\
\hline \multirow{2}{*}{ Nitrate $\mathrm{NO}_{3}-\mathrm{N}$} & $\mathrm{K}$ & 1.7 & 1.2 & $\mathbf{5 3 7 . 5}$ & 452.5 & 74.5 & 3.74 & 0.000 \\
\hline & S & 4.44 & 4.98 & 373 & 530 & 202 & -0.36 & 0.722 \\
\hline \multirow{2}{*}{ Total nitrogen TN } & $\mathrm{K}$ & 2.35 & 1.7 & 442.5 & 418.5 & 93.5 & 2.85 & 0.004 \\
\hline & $\mathrm{S}$ & 10.29 & 9.10 & 429 & 474 & 174 & 1.07 & 0.286 \\
\hline \multirow{2}{*}{ Phosphate $\mathrm{PO}_{4}$} & $\mathrm{~K}$ & 0.18 & 0.34 & 300.5 & 689.5 & 147.5 & -1.99 & 0.047 \\
\hline & S & 0.47 & 0.42 & 389 & 514 & 214 & 0.05 & 0.959 \\
\hline \multirow{2}{*}{ Total phosphorus TP } & $\mathrm{K}$ & 0.08 & 0.15 & 324.5 & 665.5 & 171.5 & -1.40 & 0.162 \\
\hline & $\mathrm{S}$ & 0.73 & 0.59 & 413 & 490 & 190 & 0.66 & 0.509 \\
\hline
\end{tabular}

The statistical value in bold means that the differences are statistically important.

oxygen forms the third. In Serafa Stream the largest group comprises dissolved oxygen, $\mathrm{NO}_{3}-\mathrm{N}, \mathrm{NO}_{2}-\mathrm{N}$, phosphates, and total phosphorus, whereas the second is composed of Kjeldahl nitrogen, total nitrogen, and ammonium nitrogen, and only $\mathrm{BZT}_{5}$ is in the third group. In both streams, values deviating from the standard are oxygen indices, but in the Krzyworzeka this is dissolved oxygen, while in the Serafa it is $\mathrm{BZT}_{5}$.

Analysis of nitrogen and phosphorus content revealed a similar N:P ratio in water of the studied streams. In the Krzyworzeka it was from 2:1 to $143: 1$ on various sampling dates, giving an average ratio $25: 1$. In the Serafa N:P ratio was from 4:1 to $106: 1$, at an average 20:1. While analyzing individual nitrogen forms it was observed that in the Krzyworzeka the ratio of $\mathrm{TN}: \mathrm{NH}_{4}-\mathrm{N}: \mathrm{NO}_{2}-\mathrm{N}: \mathrm{NO}_{3}-\mathrm{N}$ was 100:7:1:68, which denotes that total nitrogen concentration was shaped mainly by nitrate nitrogen. In the Serafa water the TN: $\mathrm{NH}_{4}-\mathrm{N}: \mathrm{NO}_{2}-\mathrm{N}: \mathrm{NO}_{3}-\mathrm{N}$ was $100: 28: 2: 51$, which means that total nitrogen concentration was strongly affected by nitrate and ammonium nitrogen concentrations. Total phosphorus concentration in the Krzyworzeka was primarily shaped by phosphate concentration (TP: $\mathrm{PO}_{4}-\mathrm{P}$ ratio was 100:67), whereas in the Serafa water TP: $\mathrm{PO}_{4}-\mathrm{P}$ ratio was over twice lower, i.e. 100:32.
The studied indices revealed a greater changeability in the Serafa water as evidenced by higher coefficient of variance, except for $\mathrm{NO}_{3}-\mathrm{N}$ and total nitrogen, which were, respectively, almost equal and equal. In the case of oxygen indices and phosphates it was twice higher in the Serafa than in the Krzyworzeka (Table 1).

Mean concentration of oxygen dissolved in the Krzyworzeka water $\left(10.98 \mathrm{mg} \cdot \mathrm{dm}^{-3}\right)$ was at class I quality $\left(\geq 7 \mathrm{mg} \cdot \mathrm{dm}^{-3}\right)$, almost twice higher than in the Serafa (5.76 $\left.\mathrm{mg} \cdot \mathrm{dm}^{-3}\right)$, which corresponded to class II $\left(\geq 5 \mathrm{mg} \cdot \mathrm{dm}^{-3}\right)$. Mean concentration of ammonium nitrogen in the Serafa water was 25-fold higher, Kjeldahl nitrogen and $\mathrm{BOD}_{5}$ 9fold, total phosphorus 7-fold and total nitrogen 5-fold higher than in the Krzyworzeka water (Table 1). Concentrations of the above-mentioned indices classified the Krzyworzeka water as of very good status (class I), whereas the Serafa water was of the status below good (BGS). Only phosphate concentration in the 2007-10 multi-annual period in the Krzyworzeka qualified its water to class II (mean value was $0.29 \mathrm{mg} \cdot \mathrm{dm}^{-3}$ and was $0.09 \mathrm{mg} \cdot \mathrm{dm}^{-3}$ higher than the limit value for class I). On the other hand, the Serafa water, due to high phosphate concentration $\left(1.36 \mathrm{mg} \cdot \mathrm{dm}^{-3}\right)$, was classified as below good status $\left(0.31 \mathrm{mg} \cdot \mathrm{dm}^{-3}\right)$. Mean concentration of $\mathrm{NO}_{3}-\mathrm{N}$ in the Krzyworzeka water was on the level of class I and in the Serafa water of class II. 
A comparative analysis of indices between the growing season and outside the growing season revealed that the values of $\mathrm{BOD}_{5}$ and Kjeldahl nitrogen were equal in both periods only in the Krzyworzeka water (Table 2). Concentration of dissolved oxygen and ammonium nitrogen in both streams and concentrations of nitrate nitrogen and total nitrogen in the Krzyworzeka water were significantly lower in the growing season. This is caused by higher air temperature, which conditions development of biological life and the utilization of oxygen and biogenic components by living organisms, mainly vegetation. Lower values of these indices and biological oxygen demand in the Serafa water in the growing season may evidence a better sewage purification in the biological process because of higher air temperature. Only phosphate concentration in the Krzyworzeka stream was markedly higher in the growing season.

Both long and periodic fluctuations of the selected factors that burden the water environment were observed dur-
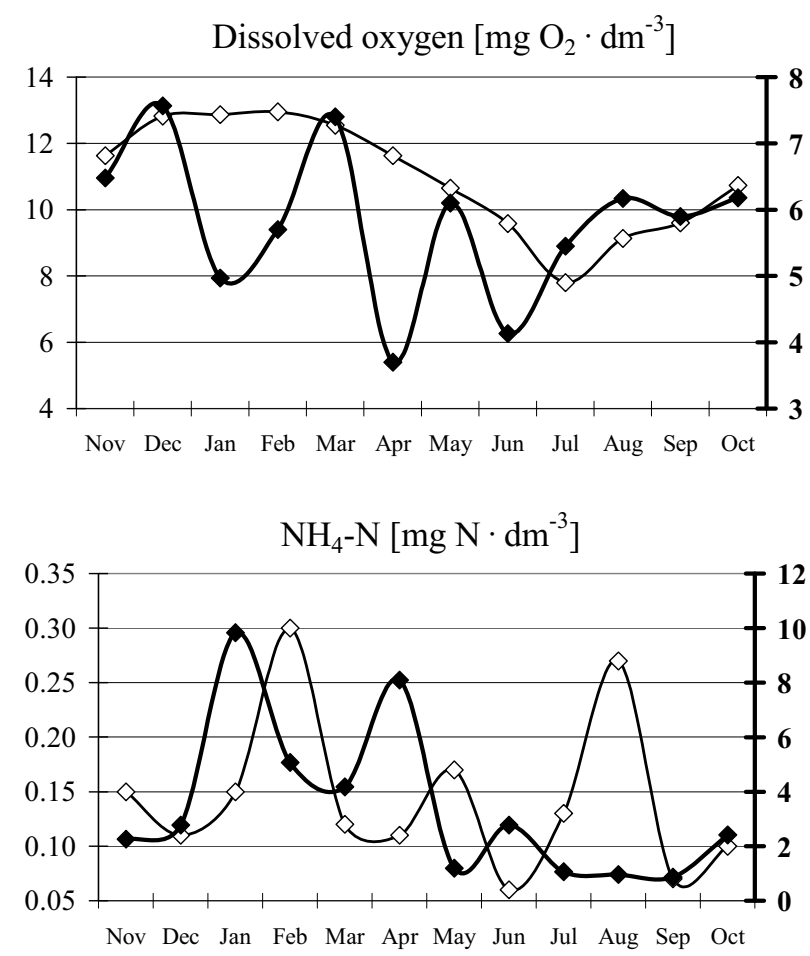

$\mathrm{TN}\left[\mathrm{mg} \mathrm{N} \cdot \mathrm{dm}^{-3}\right]$

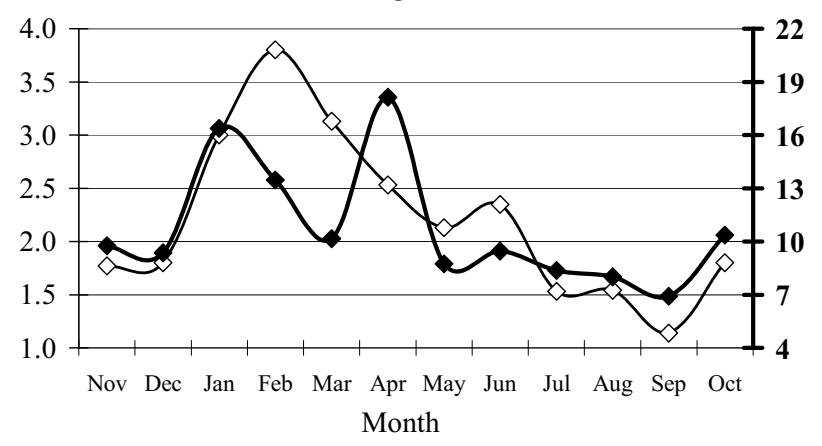

$\smile$ Krzyworzeka stream ing the period of investigations. Considering the studied indices, an obvious long-term trend was observed for concentrations of dissolved oxygen, nitrate, nitrogen, total nitrogen, and total phosphorus in the Krzyworzeka (Fig. 3). Average monthly value of dissolved oxygen concentration gradually declined from $12.9 \mathrm{mgO}_{2} \cdot \mathrm{dm}^{-3}$ in February to 7.8 $\mathrm{mgO}_{2} \cdot \mathrm{dm}^{-3}$ in July. Also, concentrations of $\mathrm{NO}_{3}-\mathrm{N}$ and total nitrogen decreased from February until August and September. Total phosphorus concentration represents an opposite tendency, since it was growing from January (0.09 $\left.\mathrm{mg} \cdot \mathrm{dm}^{-3}\right)$ to July $\left(0.39 \mathrm{mg} \cdot \mathrm{dm}^{-3}\right)$.

In the Serafa water the amplitude of fluctuations of average monthly values of studied index concentrations is much bigger, but the changes are of waving character and do not show any clear tendencies (Fig. 3). Particularly big fluctuations of $\mathrm{BOD}_{5}$ concentrations, ammonium nitrogen, and total nitrogen were noted from December to May, whereas in the other period the values were stable.
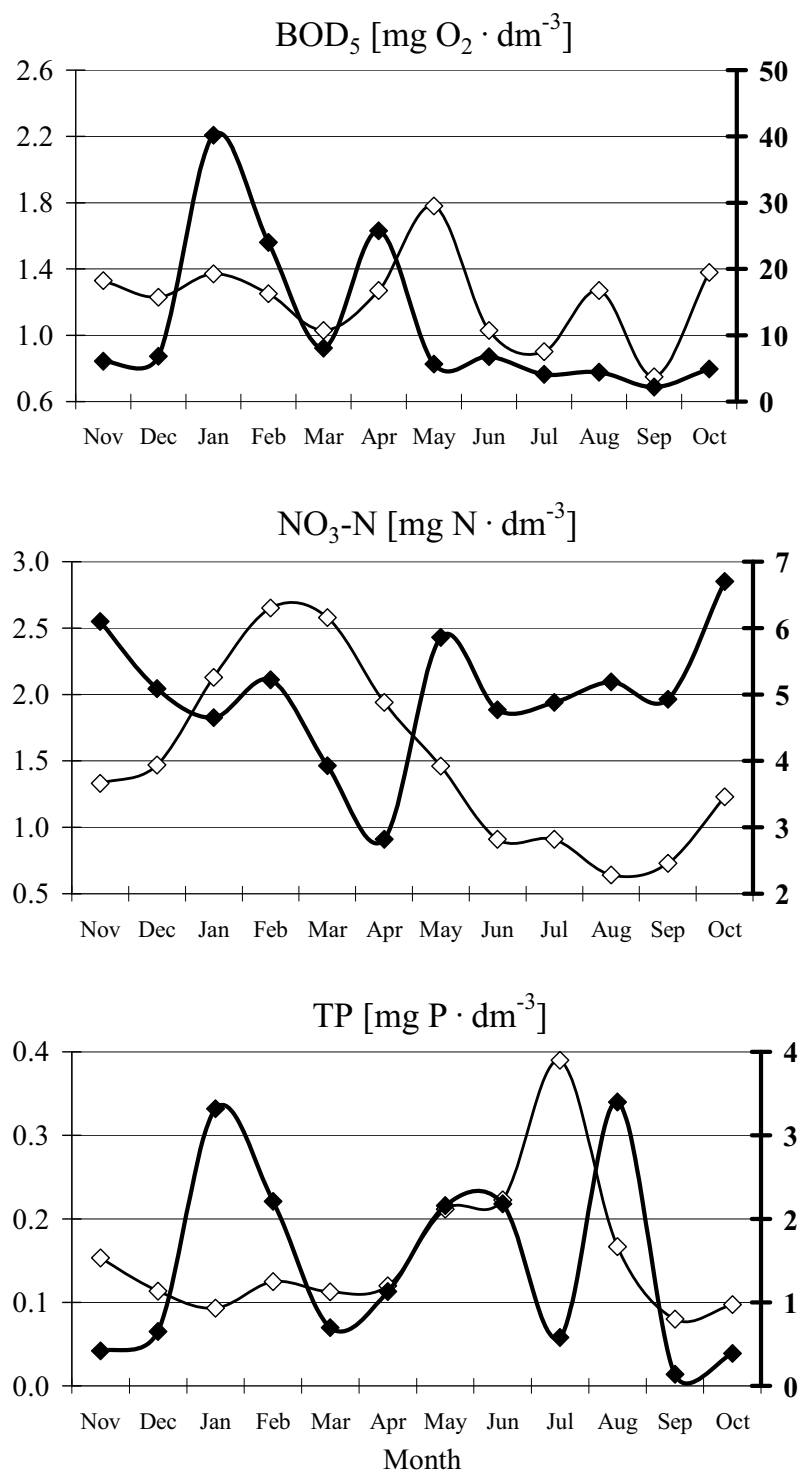

$\longrightarrow$ Serafa stream

Fig. 3. Average monthly values for the 2007-10 multiannual period of select oxygen and biogenic water indices in the Krzyworzeka and Serafa streams. 


\section{Conclusions}

In the Krzyworzeka stream water, flowing through agricultural areas, only phosphate concentrations did not fulfil the conditions for very good physicochemical status of surface waters, therefore the Krzyworzeka water was classified to quality class II. Values of the other indices were compatible with the values for these elements under undisturbed conditions, i.e. for waters of very good ecological status. On the other hand, Serafa water was highly polluted, with concentrations of $\mathrm{BOD}_{5}, \mathrm{NO}_{3}-\mathrm{N}$, ammonium nitrogen, Kjeldahl, total nitrogen, phosphate, and total phosphorus concentrations not meeting the requirements for good physicochemical status. Therefore the Serafa stream water was classified as below good status.

Statistically significant decreases in ammonium, nitrate, and total nitrogen concentrations - as well as oxygen dissolved in the Krzyworzeka - were registered during the growing season. This is due to increased nutrient uptake by plants. In the Serafa water only concentrations of dissolved oxygen and biological oxygen demand decreased statistically significantly.

Long-term tendencies of changes of the values of investigated indices were observed only in the Krzyworzeka. Concentrations of dissolved oxygen, nitrate nitrogen, total nitrogen, and total phosphorus declined from February to summer, whereas total phosphorus concentration was growing at the same time. In the spring period, at an air temperature above $5^{\circ} \mathrm{C}$, vegetation development starts, which causes a decline in biogenic compounds - mainly nitrogen concentration in surface waters. During winter, when vegetation dies, concentrations of biogenic compounds are higher.

No unanimous connection between concentrations of studied indices and water sampling date was determined in the Serafa. The stream water pollution is so serious that vegetation development and the higher intensity of biochemical processes in water do not cause an apparent reduction of biogenic component concentrations.

\section{References}

1. KOC J., SOLARSKI K., ROCHWERGER A. Effect of land reclamation system on the volume and seasonality of nitrate runoff from croplands. Journal of Elementology. 12, (2), 121, 2007.

2. KANOWNIK W., KOWALIK T., BOGDAŁ A., OSTROWSKI K. Quality categories of stream waters included in a small retention program. Pol. J. Environ. Stud. 22, (1), 159, 2013.

3. SKORBIŁOWICZ M. Identification and evaluation of pollution sources influence on quality of River Orlanka. NE Poland. Pol. J. Environ. Stud. 16, (2A), 304, 2007.

4. MOSIEJ J., PIERZGALSKI E., JEZNACH J. Contemporary issues of water management in rural areas. Advances in Agricultural Science. 63, (1), 25, 2011.

5. Directive 2000/60/EC of the European Parliament and of the Council of 23 October 2000 establishing a framework for Community action in field of water policy. OJ. L 327, 2000.
6. HERING D., BORJA A., CARSTENSEN J., CARVALHO L., ELLIOT M., FELD C.K. HEISKANEN A.S., JOHNSON R.K., MOE J., PONT D., SOLHEIM, A.L., WAN DE BUND W. The European Water Framework Directive at the age of 10: A critical review of the achievements with the recommendations for the future. Sci. Total Environ. 408, 4007, 2010.

7. PALMA P., LEDO L., SOARES S., BARBOSA I.R., ALVARENGA P. Spatial and temporal variability of the water and sediments quality in the Alqueva reservoir (Guadiana Basin; southern Portugal). Sci. Total Environ. 470-471, 780, 2014.

8. EEA (European Environmental Agency). The European environment - state and outlook 2010: synthesis. Copenhagen: European Environment Agency. 2010.

9. RAJDA W., KANOWNIK W. Some water quality indices in small watercourses in urbanized areas. Archives of Environmental Protection. 33, (4), 31, 2007.

10. FRAK M., BARYŁA A. Assessment of the state of water quality of the Dzierzgoń Lake using chemical and biological indicators. Annals of Warsaw University of Life Sciences SGWW. 44, (2), 111, 2012.

11. GHARIBI H., MAHVI A.H., NABIZADEH R., ARABALIBEIK H., YUNESIAN M., SOWLAT M.H. A novel approach in water quality assessment based on fuzzy logic. J. Environ. Manage. 112, 87, 2012.

12. SCANNAPIECO D., NADDEO V., ZARRA T., BELGIORNO V. River water quality assessment: a comparison of binary- and fuzzy logic-based approaches. Ecol. Eng. 47, 132, 2012.

13. OCAMPO-DUQUE W., OSORIO C., PIAMBA C., SCHUHMACHER M., DOMINGO J.L. Water quality analysis in rivers with non-parametric probability distributions and fuzzy inference systems: application to the Cauca River, Colombia. Environ. Int. 52, 17, 2013.

14. SHARMA A., NAIDU M., SARGAONKAR A. Development of computer automated decision support system for surface water quality assessment. Computat. Geosci. 51, 129, 2013.

15. VOYSLAVOV T., TSAKOVSKI S., SIMEONOV V. Hasse diagram technique as a tool for water quality assessment. Anal. Chim. Acta. 770, 29, 2013.

16. WANG Y., WANG P., BAI Y., TIAN Z. LI J., SHAO X., MUSTAVICH L.F., LI B.L. Assessment of surface water quality via multivariate statistical techniques: A case study of the Songhua River Harbin region, China. J. Hydro-environ. Res. 7, (1), 30, 2013.

17. WONG H., HU B.Q. Application of interval clustering approach to water quality evaluation. J. Hydrol. 491, (29), 1, 2013.

18. BORJA A., ELLIOTT M. What does 'Good Ecological Potential' mean, within the European Water Framework Directive? Mar. Pollut. Bull. 54, 1559, 2007.

19. BORJA A., TUEROS I., BELZUNCE M.J., GALPARSORO I., GARMENDIA J.M., REVILLA M., SOLAUN O., VALENCIA V. Investigative monitoring within the European Water Framework Directive: a coastal blast furnace slag disposal, as an example. J. Environ. Monit. 10, 453, 2008.

20. BOGDAŁ A., KANOWNIK W., WIŚNIOS M. Changes of values and concentrations of physicochemical quality indices of the Prądnik-Białucha River (KrakowskoCzęstochowska Upland). Gaz, Woda i Technika Sanitarna. 8, 358, 2012 [In Polish].

21. GUILLÉN D., GINEBREDA A., FARRÉ M., DARBRA R.M., PETROVIC M., GROS M., BARCELÓ D. 
Prioritization of chemicals in the aquatic environment based on risk assessment: Analytical, modelling and regulatory perspective. Sci. Total Environ. 440, 236, 2012.

22. LÓPEZ-DOVAL J.C., DE CASTRO-CATALÀ N., ANDRÉS-DOMÉNECH I., BLASCO J., GINEBREDA A., MUÑOZ I. Analysis of monitoring programs and their suitability for ecotoxicological risk assessment in four Spanish basin. Sci. Total Environ. 440, 194, 2012.

23. WIATKOWSKI M., PAUL L. Surface Water Quality Assessment in the Troja River Catchment in the Context of Włodzienin Reservoir Construction. Pol. J. Environ. Stud. 18, (5), 923, 2009.
24. POLICHT-LATAWIEC A., KANOWNIK W., ŁUKASIK D. Effect of point source pollution on the San River water quality. Infrastructure and Ecology of Rural Areas. 4, (1), 253, 2013 [In Polish].

25. HUS T., PULIKOWSKI K. Content of nitrogen compounds in waters flowing out of small agricultural catchments. Pol. J. Environ. Stud. 20, (4), 895, 2011.

26. Decree of the Ministry of Natural Environment on November 9, 2011 on the classification of the state of surface waters and environmental quality standards for priority substances. J. L. No. 257, item 1545. 2011 [In Polish]. 